\title{
Resistance to Diseases and Environmental Flexibility of Summer Rapeseed in Trans-Urals
}

\author{
A.A. Postovalov \\ Kurgan State Agricultural Academy named \\ after T.S. Maltsev, \\ Kurgan, Russia \\ e-mail: p_alex79@mail.ru
}

\author{
D.V. Gladkov \\ Kurgan State Agricultural Academy named \\ after T.S. Maltsev, \\ Kurgan, Russia \\ e-mail: gladkovden.kurgan@mail.ru
}

\begin{abstract}
The studies characterize the resistance and environmental flexibility of summer rapeseed breeds when cultivating in terms of nonfallow predecessors on fertilized and unfertilized ground in forest steppe of Trans-Urals. The following breeds demonstrated complex resistance to fusarial head blight and root rot depending on the watering conditions: Nadyozhniy 92 and SibNIIK 198. The yield of summer rapeseed breeds increased after mineral fertilization: for standard breed by 1.1 $\mathrm{q} / \mathrm{ha}$, for other breeds by $2.2-4.6 \mathrm{q} / \mathrm{ha}$. The following breeds belong to the group of widely adaptive without mineral fertilization: Ratnik, Nadyozhniy 92 and SibNIIK 21, while on fertilized ground breeds Nadyozhniy 92 and SibNIIK 21 were characterized as highly environmentally flexible. The yield of crude fat and cake of Ratnik breed amounted to 764.4 and 1217.1 $\mathrm{kg} / \mathrm{ha}$, respectively. The yield of fat and cake for other breeds reduced to $575.5 \mathrm{~kg}$ and $866.3 \mathrm{~kg}$, correspondingly. The content of erucic acid in the oil of the majority of breeds remained exceptionally low, from 0.10 to $0.13 \%$, while the content of glucos-inolates altered for different breeds from 15.68 to 27.61 $\mu \mathrm{mol} / \mathrm{g}$ of oil cake.
\end{abstract}

Keywords-summer rapeseed, breed, nutrient status, resistance to diseases, yield, environmental flexibility

\section{INTRODUCTION}

In modern production, the oil-bearing crops are called some of the most economically feasi-ble crops. Modern production of oil-bearing crops in Russia is insufficient even for internal use, while the scarcity of main oily raw materials on the market further increases the demand for such crops.

The arable farming in Urals and Siberian regions of Russia ramps up the oilseed production rate through increasing volume of summer rapeseed growing [5]. The breed is one of primary factors for increased yield and quality of arable farming products. The selectionists when creating new breeds can face a bunch of complications. For instance, adaptive selection specifies quite high re-quirements to newly created breeds (hybrids) of agricultural crops. They should combine high productivity and environmental flexibility with resistance to biotic, abiotic and edaphic stresses $[1,3]$. By developing main methods of breeding summer rapeseed in Trans-Urals, the main stake is placed on the breeds created by VNII of rapeseed and Siberian experimental facility of VNIIMK. One of the factors limiting the stable crop yield are fungus diseases that manifest at all stages of rapeseed ontogenesis $[8,2]$. A substantial opportunity for increased yield of summer rapeseed is mineral fertilization. The mineral fertilizers make summer rapeseed more resistant to adverse envi-ronmental factors, diseases, enhances biological soil activity, facilitates active development of an-tagonists for root rot excitants, accelerate the development and ripening $[4,6,9,11-15]$. To study these factors, the resistance to diseases and environmental flexibility of summer rapeseed breeds were studied in forest steppe of Trans-Urals.

\section{CONDitions, MATERIALS AND METHODS}

The field experiment performed on a test field of Kurgan SAA in 2010-2011 has compared early Dubravinskiy, Nadyozhniy 92, SibNIIK 198 and SibNIIK 21 with Ratnik breed (standard in Kur-gan region) created by the VNII of rapeseed. The evaluation used two backgrounds: 1) no fertilizers; 2) N60P30

The plot area was $4 \mathrm{~m} 2$, the record plot area was $1 \mathrm{~m} 2,6$ replications, random arrangement of vari-ants. Row sowing by SR-1 nursery planter was done on 21th and 27th of May. The predecessor was the first wheat after fallow. The agromachinery used in the experiment are conventional machines for small-seed crops. The seeds were treated by Tabu ${ }^{\circledR}(6 \mathrm{l} / \mathrm{t})$ and the vegetation by BOREY insec-ticide $(0.1$ 1/ha) to protect the crops from shield beetles and blue fleas. The weed invasions were re-moved by Fusilade Forte herbicide $(1.0 \mathrm{l} / \mathrm{ha})$. The data was collected as per commonly used tech-niques [7].

The soil of the test plot is light loam leached chernozem with medium thickness and low hu-mus content. Hydrothermal vegetation conditions during the experiment were contrasting. In the first year, the growth and development of the crops was under atmospheric and soil drought: the hydrothermal index during the vegetation of crops was 0.42 . Summer months of 2011 were charac-terized by moderate air temperature and excessive precipitation: the hydrothermal index during veg-etation of the crops was 1.31

\section{RESULTS AND DISCUSSION}

For the cultivation of summer rapeseed, the control over the development of infections that can re-duce crop yield by $20-30 \%$ is of great significance. Under the conditions of 
Trans-Urals, the most widely spread are fusarial head blight and root rot, which exciters belong to the group of soil infections as per epiphytical classification [10]. The fusarial head blight was killing plants over the whole vegetation period, while the maximum destruction was observed during the leaf rosette phase. In drought conditions of 2010, breeds Ratnik, Nadyozhniy 92 and SibNIIK 198 were characterized by increased resistance to fusarial head blight without fertilization; the perishability of the breeds was less than 15.6\% (Table 1). The breeds Dubravinskiy and SibNIIK 21 had reliably lowering resistance to the disease and were infected by fusarial head blight by $5-6 \%$ more as compared to the standard. The fertilization allowed substantially increasing the resistance of the breed to fusarial head blight (1.2-1.6 times).

TABLE I. PERISHABILITY OF SUMMER RAPESEED BREEDS

\begin{tabular}{|c|c|c|c|c|c|c|}
\hline \multirow{3}{*}{ Breed } & \multicolumn{6}{|c|}{ Infection progress [\%] } \\
\hline & \multicolumn{3}{|c|}{ fusarial head blight } & \multicolumn{3}{|c|}{ root rot } \\
\hline & 2010 & 2011 & average & 2010 & 2011 & average \\
\hline \multicolumn{7}{|c|}{ no fertilizers } \\
\hline Ratnik-st & 15.0 & 10.5 & 12.7 & 14.2 & 20.8 & 17.5 \\
\hline early Dubravinskiy & 21.4 & 16.5 & 19.0 & 14.2 & 10.8 & 14.6 \\
\hline Nadyozhniy 92 & 15.6 & 5.3 & 10.5 & 14.2 & 15.0 & 12.5 \\
\hline SibNIIK 198 & 15.3 & 2.7 & 11.5 & 18.3 & 11.7 & 15.0 \\
\hline SibNIIK 21 & 20.4 & 12.9 & 14.1 & 11.7 & 10.0 & 10.8 \\
\hline \multicolumn{7}{|c|}{$\mathrm{N}_{60} \mathrm{P}_{30}$} \\
\hline Ratnik-st & 10.0 & 5.8 & 8.1 & 11.7 & 11.7 & 11.7 \\
\hline early Dubravinskiy & 13.7 & 10.1 & 11.9 & 8.3 & 6.7 & 7.5 \\
\hline Nadyozhniy 92 & 12.8 & 12.9 & 12.9 & 18.3 & 10.0 & 14.2 \\
\hline SibNIIK 198 & 11.7 & 8.7 & 10.2 & 10.8 & 14.2 & 12.5 \\
\hline SibNIIK 21 & 13.0 & 7.6 & 10.3 & 8.3 & 12.5 & 10.4 \\
\hline $\mathrm{HCP}_{0.05}$ nutrition background & 1.6 & 0.5 & & 1.6 & 1.9 & \\
\hline breed & 2.5 & 0.8 & & 2.5 & 3.0 & \\
\hline
\end{tabular}

The infection of the breeds by root rot in 2010 was on the level of the standard $(14.2 \%)$ without fertilization, while it had no remarkable effect on the resistance of plants to the disease. Among the breeds, increased resistance was specific for early Dubravinskiy and SibNIIK $21(8.3 \%)$. The increased soil moisture in 2011 increased the perishability of the breeds only on the unfertilized ground. In addition, the early Dubravinskiy and Nadyozhniy 92 breeds demonstrated reliably low-ered rate of infection by root rot. The fertilization decreased the infection level 1.5 times; for stand-ard breed it decreased 1.8 times.

Under the conditions of drought, the studied breeds were appreciably behind the standard breed in terms of yield.
Without fertilization, the yield shortfall was $0.3-0.7 \mathrm{t} / \mathrm{ha}$ (Table 2). Fertiliza-tion that negatively affected the survivability of the plants decreased the yield of Ratnik and Na-dyozhniy 92, while the increased yield of early Dubravinskiy was still lower than that of unfertilized reference breed. The advantage of Ratnik over Siberian breeds increased under favorable watering regime: on both nutrition backgrounds, it boosted the yield by $0.53-0.94 \mathrm{t} / \mathrm{ha}$. On average over the experiment, the yield of summer rapeseed breeds increased after mineral fertilization: for standard breed by $1.1 \mathrm{q} / \mathrm{ha}$, for other breeds by $2.2-4.6 \mathrm{q} / \mathrm{ha}$.

TABLE II. PERISHABILITY OF SUMMER RAPESEED BREEDS

\begin{tabular}{|c|c|c|c|c|}
\hline \multirow{2}{*}{ Breed } & \multicolumn{3}{|c|}{ Crop capacity [t/ha] } & \multirow{2}{*}{$\mathbf{b}_{\mathbf{i}}$} \\
\hline & 2010 & 2011 & average & \\
\hline \multicolumn{5}{|c|}{ no fertilizers } \\
\hline Ratnik-st & 1.74 & 1.92 & 1.83 & 0.7 \\
\hline early Dubravinskiy & 1.00 & 1.35 & 1.18 & 1.4 \\
\hline Nadyozhniy 92 & 1.41 & 1.33 & 1.37 & -0.3 \\
\hline SibNIIK 198 & 0.90 & 1.56 & 1.23 & 2.6 \\
\hline SibNIIK 21 & 1.04 & 1.19 & 1.12 & 0.6 \\
\hline \multicolumn{5}{|c|}{$\mathrm{N}_{60} \mathrm{P}_{30}$} \\
\hline Ratnik-st & 1.51 & 2.36 & 1.94 & 2.1 \\
\hline early Dubravinskiy & 1.38 & 1.42 & 1.40 & 0.1 \\
\hline Nadyozhniy 92 & 1.38 & 1.83 & 1.61 & 1.1 \\
\hline SibNIIK 198 & 1.55 & 1.82 & 1.69 & 0.7 \\
\hline SibNIIK 21 & 1.19 & 1.59 & 1.39 & 1.0 \\
\hline $\mathrm{HCP}_{0.05}$ nutrition background & $\begin{array}{l}0.08 \\
0.08\end{array}$ & 0.27 & & \\
\hline
\end{tabular}


The evaluation of breed productivity allowed calculating the parameters of environmental flexibility that characterizes total reaction of the breed on changed environment. The rapeseed breeds with the flexibility coefficient less than 1 belong to neutral type (widely adaptive); their yield is stable. Such breeds on unfertilized background are Ratnik, Nadyozhniy 92 and SibNIIK 21. Under adverse conditions their productivity drops less. The breeds with the flexibility coefficient more than 1 are environmentally flexible (narrowly adaptive), that under optimal conditions have high yield: early Dubravinskiy and SibNIIK 198. On fertilized background, the neutral breeds are early Dubravinskiy and SibNIIK 198; the narrowly adaptive is Ratnik, and Nadyozhniy 92 and SibNIIK 21 breeds are those with high environmental flexibility (flexibility coefficient equals 1). The change of the indica-tors for the breed corresponds to the change of environmental conditions.

At favorable temperatures and precipitation, the majority of breeds increased the content of crude fat in seeds by $45 \%$ on average (Table 3). The maximum oil content was demonstrated by SibNIIK 198 (46.3\%) and SibNIIK 21 $(46.0 \%)$ that exceeded that of the standard by $0.5-0.8 \%$. Low fat content $(42.8 \%)$ was noted only in the seeds of early Dubravinskiy breed that falls behind the standard by $2.7 \%$.

The oil yield from unit area was mainly determined by the crop yield $(r=0.9)$ and less by the oil content of seeds $(r=$ 0.5 ). When expressed as dry matter (with seed humidity of $10 \%$ ), the yield of crude fat and cake of standard breed was 794.4 and $1217.1 \mathrm{~kg} / \mathrm{ha}$, respectively. As opposed to the standard, the yield of fat and cake for other breeds reduced to $575.5 \mathrm{~kg}$ and $866.3 \mathrm{~kg}$, corre-spondingly. The largest yield drop was demonstrated by early Dubravinskiy breed: oil yield was less by $255.1 \mathrm{~kg} / \mathrm{ha}$ as against the standard.

TABLE III. OIL AND CAKE YIELD FOR SUMMER RAPESEED BREEDS CULTIVATED ON N60P30 BACKGROUND

\begin{tabular}{|l|c|c|c|}
\hline \multicolumn{1}{|c|}{ Breed } & $\begin{array}{c}\text { Oil content } \\
{[\mathbf{\%}]}\end{array}$ & $\begin{array}{c}\text { Oil yield } \\
{[\mathbf{k g} / \mathbf{h a}]}\end{array}$ & $\begin{array}{c}\text { Cake yield } \\
{[\mathbf{k g} / \mathbf{h a}]}\end{array}$ \\
\hline Ratnik-st & 45.5 & 794.4 & 1217.1 \\
\hline early Dubravinskiy & 42.8 & 539.3 & 909.3 \\
\hline Nadyozhniy 92 & 45.8 & 663.6 & 1006.1 \\
\hline SibNIIK 198 & 46.3 & 704.2 & 1049.2 \\
\hline SibNIIK 21 & 46.0 & 575.5 & 866.3 \\
\hline
\end{tabular}

The content of anti-nutritional components-erucic acid and glucosinolates (thiogluco-sides) - is limited in rapeseed. The level of erucic acid in oil of the majority of breeds was excep-tionally low, from 0.10 to $0.13 \%$ (the permissible limit is $5 \%$ ). High content of erucic acid (up to $2.97 \%$ ) was specific only for early Dubravinskiy and Nadyozhniy 92 breeds (see Figure).

The content of glucosinolates complied with standards and varied depending on the breed from 15.68 to $27.61 \mu \mathrm{mol} / \mathrm{g}$ of oil cake. Only two breeds exceeded (within admissible limits) the standard: Nadyozhniy 92 and SibNIIK 21 with 27.61 and $22.70 \mu \mathrm{mol} / \mathrm{g}$, respectively.

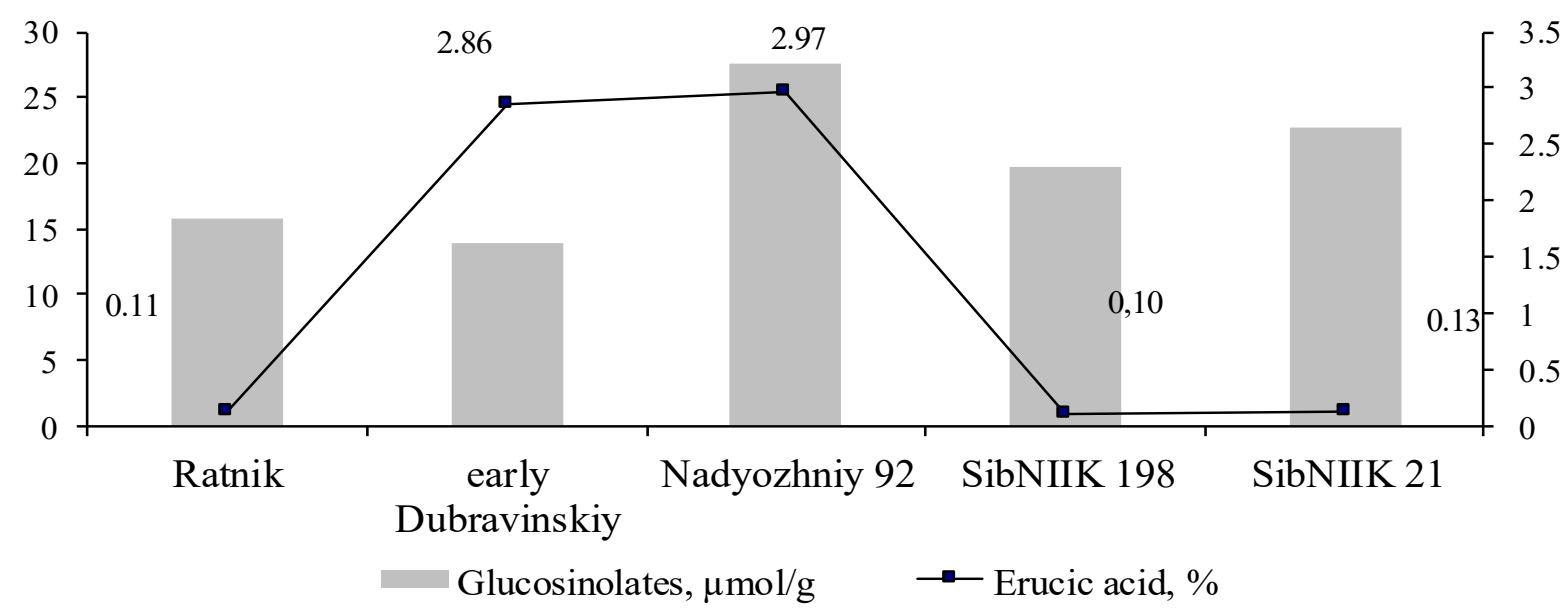

Fig. 1. Content of glucosinolates and erucic acid in oil seeds of summer rapeseed breeds

Thus, all studied breeds under the conditions of TransUrals formed the crop yield meeting the quality requirements of breeds of 00-type (erucic-less and low-glucosinolate). In terms of the combination of the indicators, the product quality was higher for breeds Ratnik, Nadyozhniy 92 and SibNIIK 198.

\section{CONCLUSION}

In the forest steppe zone of Trans-Urals, breeds Nadyozhniy 92 and SibNIIK 198 were resistant to fusarial head blight: the infection level was less than $11.5 \%$. The resistance on the fertilized back-ground was demonstrated by Ratnik, SibNIIK 198 and SibNIIK 21 breeds. The breed 
infection level by root rot on fertilized ground decreased 1.5 times.

Under the conditions of Trans-Urals forest steppe, the yield of Siberian breeds fell back from that of the standard breed. The yield of summer rapeseed breeds increased after mineral fertiliza-tion: for standard breed by $1.1 \mathrm{q} / \mathrm{ha}$, for other breeds by $2.2-4.6 \mathrm{q} / \mathrm{ha}$. The following breeds belong to the group of broadly adaptive without mineral fertilization: Ratnik, Nadyozhniy 92 and SibNIIK 21, while on fertilized ground breeds Nadyozhniy 92 and SibNIIK 21 were characterized as highly environmentally flexible.

The yield of crude fat and cake of Ratnik breed amounted to 764.4 and $1217.1 \mathrm{~kg} / \mathrm{ha}$, respec-tively. As opposed to the standard, the yield of fat and cake for other breeds reduced to $575.5 \mathrm{~kg}$ and $866.3 \mathrm{~kg}$, correspondingly. The content of erucic acid in the oil of the majority of breeds re-mained exceptionally low, from 0.10 to $0.13 \%$, while the content of glucosinolates altered for dif-ferent breeds from 15.68 to $27.61 \mu \mathrm{mol} / \mathrm{g}$ of oil cake.

\section{References}

[1] L.F. Ashmarina, I.M. Gorobey, N.M. Koniaeva, "Summer rapeseed diseases in Western Siberia" (in Russian), Bulletin of the Russian Academy of Agricultural Sciences, 2009, No. 6, pp. 36-37.

[2] L.F. Ashmarina, N.M. Konyeva, A.S. Korobeynikov, "Infection of various rapeseed breeds by most widely spread diseases in Western Siberia" (in Russian), Bulletin of Altai State Agrarian University, 2015 No. 1(34), p. 28-34.

[3] V.I. Gorshkov, "Model parameters of summer rapeseed breeds for the conditions of Central Black Earth region" (in Russian), Bulletin of Voronezh State Agrarian University, 2013, No. 2(37), pp. 74-78..

[4] E.V. Grigoryev, A.A. Postovalov, "Reaction of summer rapeseed on treatment by liquid mineral fertilizers" (in Russian), Bulleting of Ulyanovsk State Agricultural Academy, 2018, No. 1 (41), pp. 60-63.
[5] A. Yu. Izmaylov, V. P. Ilizarov, P. M. Pugachev et al, "Zonal resourcesaving technologies for cultivation, conditioning and storage of summer rapeseed in the Siberian Federal District: production and practical issue", Moscow: Rosinformagrotekh, 2011, p.52.

[6] N.N. Makoveyeva, A.A. Postovalov, "Reaction of summer rapeseed breeds on the growth conditions in Trans-Urals forest steppe", Achievements of science and engineering of AIC, 2012, No. 4, pp. 2629.

[7] V.M. Lukomets, N. M. Tishkov, V.F. Baranov et al, "Methods of field agrotechnical experiments on oil-bearing crops", V. M. Lukomets Eds., Krasnodar: AlVi disayn, 2010, p. 327.

[8] V.T. Piven, O.A. Serdyuk, "Phytosanitary monitoring of rapeseed diseases", Oil-bearing crops. Science and technology bulletin of AllRussian scientific and research institute of oil-bearing crops, No. 2, pp. 148-149, 2011.

[9] V.P. Savenkov, "Response of summer rapeseed on mineral fertilizers in the conditions of Central Black Earth region", Agrochemistry, 2010, No. 2, pp. 14-20.

[10] E.Yu. Toropova, "Ecological principles of plant protectiion from diseases in Siberia", Novosibirsk, 2005, p. 370.

[11] S. Alström, "Root-colonizing fungi from oilseed rape and their inhibition of Verticillium dahlia", Journal of Phythopatology, Vol. 148, No. 7-8, 2000, pp. 417-423.

[12] S. Deketelaere, L. Tyvaert, S.C. Franka, M. Hofte, "Desirable traits of a good biocontrol agent against Verticillium wilt", Frontiers in Microbiology, Vol. 8, No. 6, 2017.

[13] S. Hilton et al, "Preceding crop and seasonal effects influence fungal, bacterial and nematode diversity in wheat and oilseed rape rhizosphere and soil", Applied Soil Ecology, 2018, Vol. 126, pp. 34-46.

[14] V.V. Karpachev, V.P. Savenkov, L.D. Chesnokova, S.A. Kharlamov, N.L. Voropaeva, "Development of innovative technology of advanced macro -and microfertilizers application on spring rape usin gnew (nano) materials", Scientific Israel -Technological Advantages, 2014, vol. 16, No. 3, pp. 84-91.

[15] S.L. Kendall, H. Holmes, C.A. White, S.M. Clarke, P.M. Berry, "Quantifying lodging-induced yield losses in oilseed rape", Field Crops Research, 2017, Vol. 211, pp. 106-113. 